\title{
Pola Pertumbuhan Kerangka Ternak Kerbau Jantan
}

\author{
(THE SKELETAL GROWTH PATTERN OF MALE BUFFALO)
}

\author{
Fiqy Hilmawan ${ }^{1 *}$ \\ Henny Nuraini ${ }^{2}$, Rudy Priyanto ${ }^{2}$ \\ ${ }^{1}$ Balai Pengkajian Teknologi Pertanian Kalimantan Selatan, \\ Kementerian Pertanian \\ Jl. Panglima Batur Barat No.4 Kota Banjarbaru 70714 Indonesia \\ ${ }^{2}$ Departemen Ilmu Produksi dan Teknologi Peternakan, \\ Fakultas Peternakan, Institut Pertanian Bogor University \\ Kampus Dramaga IPB, Jl. Agatis, Dramaga, \\ Bogor, Jawa Barat, Indonesia 16680 \\ *Email: fiqyhilmawan@gmail.com
}

\begin{abstract}
This research was aimed to analyze the skeletal growth patterns of buffalo. Research was conducted at Kudus Livestock Market and Maeso Suro's buffalo farmer group in Kudus District, Central Java on Februari 2015 to investigate the lenght skeletal of buffalo. This research used 94 heads of male buffalo in range $I_{0}, I_{1}, I_{2}, I_{3}$ age categories. The body parameters of this research consisted of 11 parameters. The experiments used allometric model $\left(y=a \cdot e^{b x}\right)$ to study the growth patterns of bones buffalo. The results showed that the growth impetus of bones moved from the distal (os metacarpus and os metatarsus) toward proximal regions (back) and from the sacral toward to thoracic regions. The growth of bones ended at spine region $(\mathrm{b}>1)$. Study of skeletal growth in livestock (buffalo) could predicted the age of livestock based on physiological maturity of carcass.
\end{abstract}

Keywords: age of livestock; buffalo; morphometric; skeletal growth

\begin{abstract}
ABSTRAK
Ukuran tubuh pada ternak ditentukan oleh pertumbuhan tulang (kerangka) yang mencapai ukuran maksimum lebih awal dibandingkan komponen tubuh lainnya seperti otot dan lemak. Pertumbuhan tulang erat kaitannya dengan jumlah daging yang diperoleh karena tulang merupakan tempat melekatnya otot. Penelitian ini bertujuan untuk menganalisis pola pertumbuhan kerangka ternak kerbau. Penelitian ini dilaksanakan di Pasar Ternak Kudus dan Kelompok Ternak kerbau Maeso Suro, Kabupaten Kudus Jawa Tengah pada bulan Februari 2015. Sebanyak 94 ekor kerbau jantan dengan kisaran umur $\mathrm{I}_{0}(<2$ tahun), $\mathrm{I}_{1}$ (2-3 tahun), $\mathrm{I}_{2}$ (3-3.5 tahun), dan $\mathrm{I}_{3}$ (3.5-4 tahun). digunakan pada penelitian ini. Bagian kerangka yang diukur pada penelitian ini meliputi 11 variabel yang terdiri atas bagian ruas tulang belakang, ruas tulang alat gerak depan dan ruas tulang alat gerak belakang. Data yang diperoleh dianalisis dengan metode Huxley untuk menganalisis pertumbuhan alometrik kerangka tubuh ternak kerbau. Berdasarkan hasil penelitian diperoleh bahwa pola pertumbuhan tulang pada kerbau secara keseluruhan dimulai dari bagian kaki (distal) menuju ke arah badan (proximal) dan dari bagian tulang sacral menuju ke arah depan pada bagian punggung (thorax). Pertumbuhan tulang berakhir pada area komponen tulang belakang (punggung) yang memiliki nilai $b>1$. Komponen pertumbuhan kerangka memiliki kaitan dengan pertumbuhan otot untuk estimasi distribusi karkas pada ternak kerbau. Kajian pola pertumbuhan kerangka pada ternak juga dapat digunakan untuk memprediksi umur ternak berdasarkan tingkat kematangan fisiologis karkas.
\end{abstract}

Kata-kata kunci: kerbau; pertumbuhan kerangka; ukuran tubuh; umur ternak 


\section{PENDAHULUAN}

Kerbau adalah hewan ruminansia dari sub famili Bovidae yang berkembang di banyak bagian dunia dan diduga berasal dari daerah India. Kerbau domestikasi atau water bufallo berasal dari spesies Bubalus arnee (Hasinah dan Handiwirawan, 2006). Ternak kerbau dimanfaatkan sebagai ternak potong dan tenaga kerja dalam mengolah sawah atau sebagai alat transportasi pertanian karena memiliki watak yang tenang, mudah dilatih, tenaga yang kuat, dan daya adaptasi yang baik di lingkungan tropis. Selain digunakan sebagai ternak potong dan kerja, kerbau juga berperan penting dalam kehidupan masyarakat Indonesia di antaranya sebagai komponen penting dalam kehidupan sosial budaya masyarakat, agrowisata dan olah raga (Thalib dan Naim, 2012).

Ukuran tubuh ternak dapat digunakan sebagai identifikasi ternak dan indikator tingkat produktivitas ternak. Ternak kerbau termasuk dalam ternak tipe kerangka sedang karena memiliki ukuran tubuh yang tidak besar yang dapat dilihat dari bobot badan dan tingkat produksi daging. Pembentukan kerangka tubuh dipengaruhi oleh pertumbuhan dan perkembangan ternak. Pertumbuhan merupakan perubahan ukuran-ukuran dari bobot hidup, bentuk, dan komponen tubuh (otot, tulang, dan lemak). Perkembangan merupakan perubahan konformasi tubuh dan bentuk serta fungsi tubuh sehingga dapat digunakan secara penuh. Tingkat pertumbuhan didasarkan pada dua hal, yaitu bertambahnya bobot badan dan perubahan ukuran-ukuran tubuh.

Kecepatan pertumbuhan ternak diawali secara perlahan, kemudian berjalan lebih cepat dan saat dewasa kembali melambat. Harapin (2005) menyatakan pola pertumbuhan pada ternak diawali dari bagian kaki (distal) menuju ke arah badan (proksimal). Pada bagian tungkai kaki (shin) depan menuju ke pangkal lengan (blade), dada (brisket) dan pundak (chuck), sedangkan dari tungkai kaki belakang (shank) menuju abdomen (flank), pangkal paha (rump) terus ke arah pinggang (loin). Pada bagian dorsal tubuh terlihat pola pertumbuhan diawali dari bagian leher dan punggung (chuck) menuju punggung (cuberoll) dan terhenti di pinggang (loin). Hal ini dapat disimpulkan bahwa bagian tubuh yang paling lambat tumbuh adalah bagian pinggang (loin), sedangkan yang paling awal bertumbuh adalah tungkai kaki dan kepala (cranium).
Berdasarkan hasil penelitian tersebut maka dilakukan penelitian mengenai pola pertumbuhan tulang/kerangka dari ternak kerbau, mengingat ternak kerbau merupakan salah satu ternak ruminansia yang potensial dikembangkan sebagai ternak dwiguna yaitu sebagai ternak potong maupun ternak kerja. Selain itu juga pertumbuhan tulang ini erat kaitannya dengan tingkat produktivitas daging karena tulang merupakan tempat melekatnya daging. Hasil penelitian Priyanto et al. (2009) tentang pertumbuhan tulang yang dihubungkan pada bagian potongan komersial karkas memperlihatkan pertumbuhan tulang menunjukkan pola yang kurang jelas, namun sebagian besar pertumbuhan tulang dapat diidentifikasi polanya. Penelitian ini bertujuan untuk mengetahui pola pertumbuhan kerangka ternak kerbau sebagai salah satu informasi produktivitas karkas ternak kerbau.

\section{METODE PENELITIAN}

Penelitian ini dilakukan pada bulan Februari 2015 di Pasar Ternak Kudus dan Kelompok Ternak Kerbau Maeso Suro di Kabupaten Kudus Provinsi Jawa Tengah. Penelitian ini menggunakan ternak kerbau jantan sebanyak 94 ekor dengan kisaran umur $\mathrm{I}_{0}$ sampai $\mathrm{I}_{3}$. Ketentuan umur kerbau yaitu $\mathrm{I}_{0}$ (umur $<2$ tahun), $\mathrm{I}_{1}$ (2-3 tahun), $\mathrm{I}_{2}$ (3-3.5 tahun), $\mathrm{I}_{3}$ (3.5-4 tahun).

\section{Prosedur Penelitian}

Pengamatan morfometrik tubuh ternak dilakukan dengan mengukur bagian tubuh ternak kerbau. Pengukuran konformasi kerangka dilakukan dengan memanfaatkan penonjolan tulang baik bungkul (tuberositas), penjuluran (processus) maupun persendian (articulatio) dari seluruh pertulangan yang terlihat jelas pada ternak hidup. Hasil pengukuran kemudian dicatat.

\section{Peubah Pengamatan}

Peubah yang diamati pada penelitian ini berdasarkan WAVA (2012), yaitu 1) ossa vertebrae cervicales yang diukur dari persendian atlantoaxial hingga pangkal leher bagian dorsal, 2) ossa vertebrae thoracicae yang diukur dari pangkal leher hingga titik tengah tubuh bagian dorsal, 3) ossa vertebrae lumbales yang diukur dari titik tengah tubuh bagian dorsal hingga processus spinosus pertama tulang sacrum, 4) 
ossa vertebrae sacrales yang diukur di sepanjang tulang sacrum, 5) os scapula yang diukur dari titik tertinggi tubuh hingga tuber humerus, 6) os humerus yang diukur dari tuber humerus hingga di titik tengah tuber radius-ulna, 7) os radius-ulna yang diukur dari tuber radius-ulna hingga ossa carpi, 8) os metacarpale yang diukur dari ossa carpi hingga pangkal os phalanx I, 9) os femoris yang diukur dari tuber ilium hingga tuber femoris, 10) os tibia-fibula yang diukur dari tuber femoris hingga tuber calcis, 11) os metatarsale yang diukur dari pangkal os tarsus hingga os phalanx 1. Skema pengukuran pada ternak kerbau disajikan pada Gambar 1.

\section{Analisis Data}

Pertumbuhan kerangka/tulang pada kerbau dianalisis menggunakan persamaan alometrik Huxley (1932) yaitu $\mathrm{Y}=\mathrm{aX} \mathrm{X}^{\mathrm{b}}$ yang ditransformasikan terlebih dahulu ke dalam bentuk persamaan logaritma yaitu Log $\mathrm{Y}=\mathrm{Log}$ $\mathrm{a}+\mathrm{bLog} \mathrm{X}$. Dalam hal ini a= suatu konstanta (intersep); $b=$ koefisien pertumbuhan tulang; dan $\mathrm{X}=$ total ukuran linier panjang tulang (ossa vertebrae cervicales, ossa vertebrae thoracicae, ossa vertebrae lumbales, ossa vertebrae sacrales, os scapula, os humerus, os radius-ulna, os metacarpale, os femoris, os tibia-fibula, os metatarsale); $\mathrm{Y}=$ ukuran linier tulang pada tubuh ternak kerbau. Pertumbuhan linier tulang pada kerbau dimulai dari tulang dengan koefisien pertumbuhan rendah mengarah ke tulang dengan nilai koefisien pertumbuhan yang lebih tinggi.

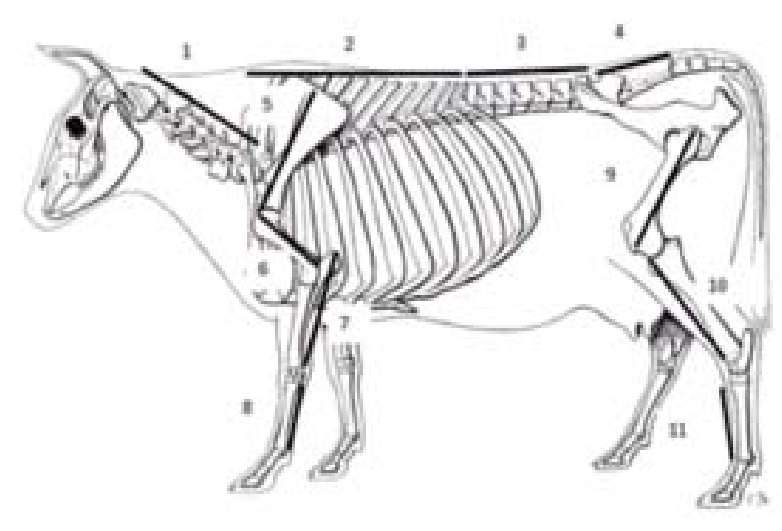

Gambar 1. Skema pengukuran pada ternak kerbau

\section{HASIL DAN PEMBAHASAN}

Pertumbuhan dapat diartikan sebagai pertambahan massa tubuh per satuan waktu. Kecepatan pertumbuhan dan distribusi dari komponen-komponen tubuh seperti tulang, otot dan lemak berlangsung secara gradual dengan jaringan tulang yang tumbuh lebih awal, kemudian diikuti jaringan otot dan jaringan lemak. Perkembangan diartikan sebagai perubahan bentuk dan komposisi tubuh sebagai akibat perbedaan kecepatan pertumbuhan relatif dari berbagai komponen tubuh (Berg dan Butterfield, 1976; Aberle et al., 2001).

Pertumbuhan kerangka/tulang ternak dapat diketahui melalui pengukuran pertumbuhan relatif komponen tulang tubuh, yakni melalui persamaan alometrik Huxley (1932) yaitu $\mathrm{Y}=\mathrm{a} \mathrm{X}^{\mathrm{b}}$. Persamaan tersebut memperlihatkan gambaran pertumbuhan tulang atau komponen tubuh secara kuantitatif. Penggunaan persamaan ini berdasarkan asumsi bahwa perubahan relatif tulang atau komponen tubuh selama pertumbuhan lebih dipengaruhi oleh faktor bobot hidup, dibandingkan dengan waktu yang diperlukan untuk mencapai ukuran tersebut. Kajian mengenai sistem kerangka dinilai sangat penting karena tulang berfungsi sebagai pemberi bentuk tubuh, tempat melekatnya otot dan perlindungan bagi organorgan vital. Nilai koefisien pertumbuhan kerangka terhadap total ukuran panjang kerangka tubuh kerbau disajikan pada Tabel 1.

Berdasarkan Tabel 1 diketahui bahwa koefisien pertumbuhan penyusun tulang belakang kerbau (ossa vertebrae cervicales, ossa vertebrae thoracicae, ossa vertebrae lumbales, ossa vertebrae sacrales) adalah 1,283; 1,339; 1,229; dan 0,985. Koefisien pertumbuhan penyusun tulang belakang kerbau menunjukkan nilai lebih dari satu, kecuali ossa vertebrae sacrales. Hal ini menunjukkan bahwa kelompok tulang tersebut berkembang lebih lambat dibanding dimensi tulang secara keseluruhan. Namun, memiliki pertumbuhan yang tinggi $(b>1)$ dan ossa vertebrae sacrales menunjukkan pertumbuhan tulang yang konstan $(b=1)$. Pertumbuhan ossa vertebrae cervicales atau tulang leher yang tinggi pada kerbau terlihat dari ukuran leher kerbau yang besar. Hasil penelitian Johnson et al. (2002) menyatakan komposisi bobot tulang cervical pada kerbau mencapai $8,1 \%$ dari total bobot tulang. Bobot 
Tabel 1. Koefisien pertumbuhan kerangka terhadap panjang kerangka tubuh kerbau.

Kerangka Tubuh

Kerangka Tubuh

Ossa vertebrae cervicales

Ossa vertebrae thoraciceae

Ossa vertebrae lumbales

Ossa vertebrae sacrales

Os scapula

Os humerus

Ossa radius ulna

Ossa metacarpale

Os femoris

Ossa tibia-fibutla

Os metatarsale

$b=$ koefisien pertumbuhan

$\mathrm{SE}=$ Standar eror

tulang leher pada kerbau lebih besar dibandingkan pada sapi Bos indicus (Brahman) yaitu hanya sebesar $7,3 \%$ dari total bobot tulang sehingga memungkinkan pertum-buhan tulang leher pada kerbau lebih tinggi.

Kerbau memiliki ukuran ossa vertebrae thoraciae dan ossa vertebrae lumbales yang besar sehingga memengaruhi potongan komersial loin pada kerbau. Potongan loin merupakan nilai terpenting dari keseluruhan potongan karkas, karena memiliki tingkat keempukan daging yang tinggi, sehingga diminati konsumen dan bernilai ekonomis tinggi. Daging bagian loin memiliki tekstur lebih empuk karena mengandung protein kolagen jaringan ikat yang lebih rendah dibandingkan pada bagian paha. Selain itu bahwa bagian primal karkas loin memiliki daya ikat air yang tinggi (Pangestika et al., 2017). Daya ikat air yang tinggi juga dapat disebabkan oleh kandungan lemak dalam daging. Daging dengan kandungan lemak intramuskuler yang tinggi juga dapat mempunyai daya ikat air yang lebih tinggi.

Koefisien pertumbuhan pada tulang penyusun alat gerak kaki depan kerbau yaitu os scapula, os humerus, os radius ulna, os metacarpale masing-masing sebesar 1,181 ; 1,$073 ; 0,785 ;$ dan 0,570 . Koefisien pertumbuhan tulang penyusun alat gerak belakang (os femoris, os tibia fibula, ossa metatarsale) adalah $0,-926$; 0,679; dan 0,540. Berdasarkan nilai koefisien tersebut ( $b$ L menunjukkan bahwa ossa metacarpale dan os metatarsale tumbuh lebih awal dibandingkan dimensi tulang secara keseluruhan dan memiliki kemampuan pertumbuhan yang rendah $(b<1)$. Berdasarkan koefisien nilai $b$ pada kerbau $(b=1)$ menunjukkan bahwa os femoris pada kerbau merupakan tulang yang berkembang/tumbuh secara konstan.

Kerbau memiliki pertumbuhan tulang belakang yang lebih baik dibandingkan pertumbuhan komponen tulang kaki, sehingga ukuran badan kerbau lebih panjang dibandingkan ukuran kaki. Ternak kerbau sering dimanfaatkan sebagai ternak dwiguna yaitu sebagai ternak potong dan ternak kerja. Tipe ternak kerja yang baik adalah ternak yang memiliki kaki yang panjang dengan panjang badan yang relatif pendek atau kaki yang pendek dengan badan yang lebih panjang. Bagian kaki (metacarpale dan metatarsale) pada kerbau yang pendek namun ukurannya lebar dan besar ini digunakan sebagai penopang tubuh kerbau yang besar agar seimbang saat berdiri maupun beraktivitas. Kerbau dengan badan yang besar juga memengaruhi kapasitas rongga dada untuk kekuatan kerja ternak (Hilmawan et al., 2016)

\section{Pola Pertumbuhan Kerangka Ternak Kerbau}

Berdasarkan nilai $b$ pada kerbau dapat diketahui pola pertumbuhan kerangka ternak. Pertumbuhan kerangka dimulai dari nilai $b$ yang rendah menuju ke nilai $b$ yang tinggi. Pola pertumbuhan kerangka kerbau disajikan pada Gambar 2.

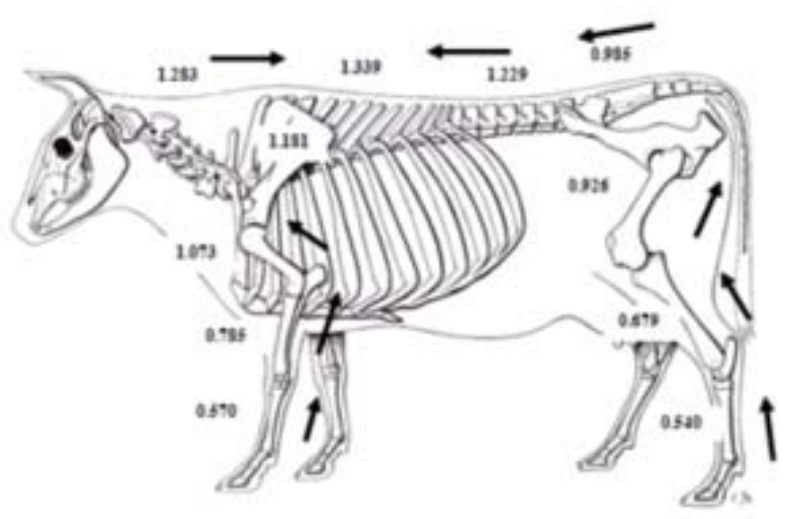

Gambar 2. Pola pertumbuhan kerangka pada kerbau 
Pada tubuh bagian depan, pertumbuhan kerangka ternak kerbau dimulai dari bagian tulang kaki depan (os metacarpale ke os radiusulna) menuju ke tubuh bagian atas (badan). Begitu pula pada bagian belakang ternak, pertumbuhan dimulai dari bagian tulang kaki belakang (os metatarsale ke os tibia-fibulla) menuju ke arah pinggang/pinggul. Pertumbuhan tulang berakhir pada area komponen tulang belakang (punggung) yang memiliki nilai $b>1$. Berdasarkan nilai koefisien $b$ pada bagian tulang belakang, pertumbuhan tulang ossa vertebrae sacrales lebih awal tumbuh, diikuti tulang ossa vertebrae lumbales, dan ossa vertebrae thoracicae.

Titik awal pertumbuhan tulang pada ternak dimulai dari bagian dengan koefisien pertumbuhan yang rendah menuju ke koefisien pertumbuhan tinggi. Hal ini dapat dilihat dari besaran nilai koefisien pertumbuhan pada bagian kerangka ternak kerbau. Hasil penelitian ini membuktikan bahwa os metatarsus dan os metacarpus adalah pusat pertumbuhan badan yang kedua, karena gelombang pertumbuhan kedua mulai dari daerah ini dan bergerak ke atas sepanjang kakikaki depan dan belakang serta tubuh dan berakhir di daerah pinggang. Area pinggang (regio lumbaris) adalah bagian tubuh yang berkembang terakhir (Sampurna dan Suatha, 2010). Hal ini sejalan dengan Berg et al. (1978) dan Aberle et al. (2001) yang menyatakan tulang belakang bagian Ossa vertebrae sacrales mencapai dewasa sebelum Ossa vertebrae lumbales dan Ossa vertebrae sacrales mencapai dewasa sebelum tulang belakang bagian Ossa vertebrae thoracicae. Bagian kaki mengalami pertumbuhan lebih awal dengan tingkat pertumbuhan yang rendah. Pertumbuhan tulang pada ternak kerbau dimulai dari bagian tulang yang tumbuh awal (tulang tungkai) ke arah proximal tubuh menuju panggul (pelvis) dan pinggang (lumbar). Pinggang merupakan bagian tubuh yang paling akhir mencapai pertumbuhan maksimal (late maturity). Jones et al. (1978) menyatakan tulang yang paling akhir tumbuh adalah tulang rusuk dan tulang pinggul dengan nilai koefisien pertumbuhan tulang yang tinggi $(b>1)$.

Berg et al. (1978) menyatakan bagian kaki berfungsi sebagai alat gerak utama dan juga sebagai penopang tubuh ternak, sedangkan badan terutama bagian punggung mengalami tumbuh terakhir dan lambat dalam mencapai ukuran dewasa. Bagian tubuh yang berfungsi lebih awal atau lebih dini (kepala dan kaki) akan berkembang lebih dulu, demikian juga bagian tubuh yang komponennya sebagian besar terdiri dari tulang. Kecepatan pertumbuhan tulang tanpa ada pengaruh dari pakan yang diberikan, maka tulang kaki berkembang paling awal, disusul oleh tulang badan dan otot, sedangkan lemak tumbuh paling lambat. Hal ini disebabkan pertumbuhan dan perkembangan tubuh dimulai dari bagian depan (kepala) bergerak ke bagian belakang tubuh dan bagian tubuh yang lain mulai dari ujung kaki menyebar ke atas (Gambar 2). Kedua pertumbuhan ini bertemu pada bagian tengah tubuh yang disebut dengan pertumbuhan antero-posterior dan centripetal. Bagian tulang penyusun alat gerak tumbuh lebih awal dibandingkan tulang penyusun sumbu tubuh, hal ini disebabkan oleh sapi atau kerbau merupakan hewan presocial yaitu lahir dengan mata terbuka dan dapat segera berdiri dan berjalan sehingga membutuhkan perkembangan alat gerak yang lebih dini.

Hasil penelitian Priyanto et al. (2009) terkait pertumbuhan tulang yang dihubungkan pada bagian potongan komersial karkas diketahui pertumbuhan tulang memperlihatkan pola yang kurang jelas, namun sebagian besar pertumbuhan tulang dapat diidentifikasi polanya. Tulang pada area kaki memiliki nilai koefisien yang terendah dengan arah pertumbuhannya dari bagian potongan komersial shin (Os metacarpale dan os metatarsale) menuju ke bagian thoraks dan dari area chuck menuju ke belakang ke area brisket. Pola pertumbuhan tulang yang lainnya yaitu dimulai dari area shank menuju ke area tubuh bagian belakang atas (rump). Komponen pertumbuhan kerangka pada kerbau memiliki kaitan dengan pertumbuhan otot. Pola pertumbuhan otot sama dengan pola pertumbuhan tulang.

\section{Hubungan Pola Pertumbuhan Kerangka dengan Umur Ternak}

Kajian pola pertumbuhan kerangka pada ternak ini dapat digunakan untuk memprediksi umur ternak berdasarkan tingkat kematangan fisiologis karkas. Kajian ini didasarkan pada bentuk, ukuran dan proses pembentukan (osifikasi) tulang padat dan rawan serta kondisi pada area tulang belakang/spinal. Menurut Tatum (2007) menyatakan tingkat kematangan karkas dan umur fisiologis ternak dibedakan menjadi lima yaitu tingkat kematangan A, B, 
Tabel 2. Indikator tingkat kematangan karkas dan hubungannya dengan umur ternak

\begin{tabular}{|c|c|c|c|c|c|}
\hline \multirow{2}{*}{ Kondisi } & \multicolumn{5}{|c|}{ Tingkat Kematangan } \\
\hline & A & $\mathrm{B}$ & $\mathrm{C}$ & $\mathrm{D}$ & $\mathrm{E}$ \\
\hline Sacral & $\begin{array}{l}\text { Sudah } \\
\text { memisah }\end{array}$ & $\begin{array}{l}\text { Osifikasi } \\
\text { sempurna }\end{array}$ & $\begin{array}{l}\text { Osifikasi } \\
\text { sempurna }\end{array}$ & $\begin{array}{l}\text { Osifikasi } \\
\text { sempurna }\end{array}$ & $\begin{array}{l}\text { Osifikasi } \\
\text { sempurna }\end{array}$ \\
\hline Lumbar & $\begin{array}{l}\text { Masih ada } \\
\text { kartilago, } \\
\text { berrongga }\end{array}$ & $\begin{array}{l}\text { Proses } \\
\text { osifikasi } \\
\text { hampir selesai }\end{array}$ & $\begin{array}{l}\text { Osifikasi } \\
\text { selesai }\end{array}$ & $\begin{array}{l}\text { Osifikasi } \\
\text { selesai }\end{array}$ & $\begin{array}{l}\text { Osifikasi } \\
\text { selesai }\end{array}$ \\
\hline Thorax & $\begin{array}{l}\text { Masih ada } \\
\text { kartilago, } \\
\text { berrongga }\end{array}$ & $\begin{array}{l}\text { Terlihat masih } \\
\text { mengalami } \\
\text { osifikasi }\end{array}$ & $\begin{array}{l}\text { Masih } \\
\text { mengalami } \\
\text { osifikasi } \\
\text { sebagian }\end{array}$ & $\begin{array}{l}\text { Osifikasi } \\
\text { hampir } \\
\text { selesai, } \\
\text { kartilago } \\
\text { masih terlihat }\end{array}$ & $\begin{array}{l}\text { Osifikasi } \\
\text { selesai, tulang } \\
\text { sudah kompak }\end{array}$ \\
\hline Rusuk & $\begin{array}{l}\text { Warna merah } \\
\text { cerah, pipih }\end{array}$ & $\begin{array}{l}\text { Agak luas dan } \\
\text { rata/pipih }\end{array}$ & $\begin{array}{l}\text { Cukup lebar } \\
\text { dan agak rata }\end{array}$ & $\begin{array}{l}\text { Cukup lebar } \\
\text { dan rata }\end{array}$ & $\begin{array}{l}\text { Lebar dan } \\
\text { rata/pipih }\end{array}$ \\
\hline $\begin{array}{l}\text { Warna } \\
\text { lean }\end{array}$ & $\begin{array}{l}\text { Merah cerah } \\
\text { ke merah } \\
\text { keabu-abuan }\end{array}$ & $\begin{array}{l}\text { Merah cerah } \\
\text { ke merah } \\
\text { gelap }\end{array}$ & $\begin{array}{l}\text { Agak merah } \\
\text { gelap }\end{array}$ & $\begin{array}{l}\text { Agak merah } \\
\text { gelap ke } \\
\text { merah gelap }\end{array}$ & Merah gelap \\
\hline $\begin{array}{l}\text { Tekstur } \\
\text { lean }\end{array}$ & $\begin{array}{l}\text { Sangat } \\
\text { baik/lembut }\end{array}$ & Baik/lembut & Cukup baik & $\begin{array}{l}\text { Agak } \\
\text { keras/kesat }\end{array}$ & Keras/kesat \\
\hline $\begin{array}{l}\text { Warna } \\
\text { tulang }\end{array}$ & Merah cerah & Merah & Agak merah & Agak putih & Putih \\
\hline
\end{tabular}

Keterangan: A (umur ternak 9-30 bulan), B (umur ternak 30-42 bulan), C (umur ternak 42-72 bulan), D (umur ternak 72-96 bulan, E (lebih dari 96 bulan).

C, D, dan E seperti yang disajikan pada Tabel 2.

Tingkat kematangan karkas dinilai sangat penting untuk mengetahui kisaran umur potong pada ternak kerbau. Tabel 2 menunjukkan bahwa kondisi osifikasi dan tingkat kematangan karkas, ossa vertebrae sacrales mengalami osifikasi lebih awal dibandingkan dengan ossa vertebrae lumbales dan ossa vertebrae thoracicae yang terlihat dari ossa vertebrae sacrales yang sudah mengalami osifikasi sempurna (tulang sudah kompak) dibandingkan ossa vertebrae lumbales dan ossa vertebrae thoracicae. Pada penelitian ini ternak kerbau yang digunakan sampai umur $\mathrm{I}_{3}$ (umur d" 4 tahun) maka dapat diindikasikan bahwa kondisi tulang belakangnya sebagian besar sudah mengalami osifikasi sempurna. Selain itu tingkat kematangan karkas kerbau pada penelitian ini berada pada kisaran grade $\mathrm{A}$ sampai grade $\mathrm{C}$ (berdasarkan umur), dengan warna dan tekstur lean yang masih cukup baik sehingga karkas yang dihasilkan masih dapat diterima oleh konsumen.

Tampilan fisik seekor ternak merupakan suatu hasil proses pertumbuhan yang berkesinambungan dengan setiap bagian tubuh mempunyai kecepatan pertumbuhan atau perkembangan berbeda. Berdasarkan laju pertumbuhan maksimumnya, urutan pertumbuhan jaringan tubuh diawali oleh jaringan saraf, tulang, otot, dan terakhir adalah lemak. Semua bagian tubuh hewan tumbuh dengan cara teratur, dan dengan laju yang berbeda dari lahir sampai dewasa. Pola pertumbuhan tersebut dapat diprediksi melalui perubahan ukuran-ukuran tubuh. Fenomena pertumbuhan ini dapat dilihat dari tulang yang merupakan komponen tubuh yang mengalami pertumbuhan paling dini setelah jaringan saraf.

\section{SIMPULAN}

Pola pertumbuhan kerangka kerbau memiliki arah yang sama yaitu dimulai dari bagian kaki (distal) menuju ke arah badan (proximal) dan dari bagian tulang sacral menuju ke arah depan pada bagian thorax. Pertumbuhan kerangka pada kerbau memiliki kaitan dengan pertumbuhan otot untuk estimasi distribusi karkas. Kajian pola pertumbuhan kerangka pada studi ini dapat digunakan untuk memprediksi umur ternak berdasarkan tingkat kematangan fisiologis karkas. 


\section{SARAN}

Diperlukan penelitian lanjutan mengenai pola pertumbuhan dan distribusi daging pada ternak kerbau untuk mengetahui estimasi produktivitas karkas pada ternak kerbau.

\section{UCAPAN TERIMA KASIH}

Penulis mengucapkan terima kasih kepada Bidang Peternakan Dinas Pertanian dan Pangan Kabupaten Kudus khususnya ke UPT Pasar Ternak Kudus dan Kelompok Ternak Kerbau Maeso Suro Kabupaten Kudus yang atas izin, bantuan, dan kerjasama selama penulis melakukan penelitian.

\section{DAFTAR PUSTAKA}

Aberle ED, Forrest JC, Gerrard DE, Mills EW. 2001. Principles of Meat Science. Fourth Edition. Iowa (US). Kendall/Hunt Publishing Company.

Berg RT, Butterfield RM. 1976. New Concepts of Cattle Growth. Sydney. University Press.

Berg RT, Andersen BB, Liboriussen T. 1978. Genetic influence on patterns of fat growth and distribution in young bulls. Anim Prod 27: $63-69$

Harapin HH. 2005. Kajian Pertumbuhan dan Distribusi Daging serta Estimasi Produktivitas Karkas Sapi Hasil Penggemukan. (Disertasi). Bogor. Institut Pertanian Bogor.

Hasinah H, Handiwirawan E. 2006. Keragaman genetik ternak kerbau di Indonesia. Di dalam: Lokakarya nasional usaha ternak kerbau mendukung program kecukupan daging sapi 2006. [Internet]. [waktu dan tempat pertemuan tidak diketahui]. Bogor (ID): Puslitbangnak. hlm 89-95; [diunduh 2019 Oktober 18]. Tersedia pada: http:// peternakan.litbang.pertanian.go.id/fullteks/ lokakarya/lkbo06-10.pdf

Hilmawan F, Nuraini H, Priyanto R, Putra BW. 2016. Pengukuran morfometrik sapi peranakan ongole dan kerbau jantan dengan metode citra digital. Jurnal Veteriner 17(4): 587-596.
Huxley JS. 1932.Problems of Relative Growth. First Ed. London. Methuen.

Johnson ER, Charles DD, Baker DA. 2002. The distribution of muscle and bone weight in swamp buffalo (Bubalus bubalis), Bos indicus and Bos taurus steers. Pertanika $J$ Trop Agric Sci 25(1): 19-26.

Jones SDM, Price MA, Berg RT. 1980. The growth and distribution of muscle in bulls and heifers of two breeds. J Anim Sci 60: 669-675.

Pang R, Septinova D, Adhianto K. 2017. Kualitas fisik pada potongan primal karkas sapi krui betina di Kabupaten Pesisir Barat Lampung. Jurnal Riset dan Inovasi Peternakan 1(3): 16-20.

Priyanto R, Johnson ER, Taylor DG. 2009. The growth patterns of carcass tissues within wholesale cuts in fattening steer. $J$ Indonesian Trop Anim Agric 34 (3): 153159.

Sampurna IP, Suatha IK. 2010. Pertumbuhan alometri dimensi panjang dan lingkar tubuh sapi bali jantan. Jurnal Veteriner 11(1): 4651.

Tatum JD. 2007. Beef grading. Di dalam: Tatum JD. Animal age, physiological maturity and associated effects on beef tenderness [internet]. Colorado (US): Colorado State University. [diunduh 2016 Jan 16]. Tersedia pada: http://www.beefresearch.org/CMDocs/ BeefResearch/PE_White_\%20Papers / Animal_Age.pdf.

Thalib C, Naim M. 2012. Grand design perbibitan kerbau nasional. Di dalam: Lokakarya Nasional Perbibitan Kerbau 2012. [Internet].2012 Sept 13-15; Bogor, Indonesia. Bogor. Puslitbangnak. Hlm. 825; diunduh 2019 Des 23]. Tersedia pada: http://peternakan.litbang.pertanian.go.id/ fullteks/lokakarya/perbibitan_kerba u_2012/perbibitan_kerbau_2012.pdf.

[WAVA] World Association of Veterinary Anatomist. 2012. Nomina Anatomica Veterinaria. 5th edition. Hannover (DE), Columbia (US), Ghent (BE), Sapporo (JP): Editorial Committee. 